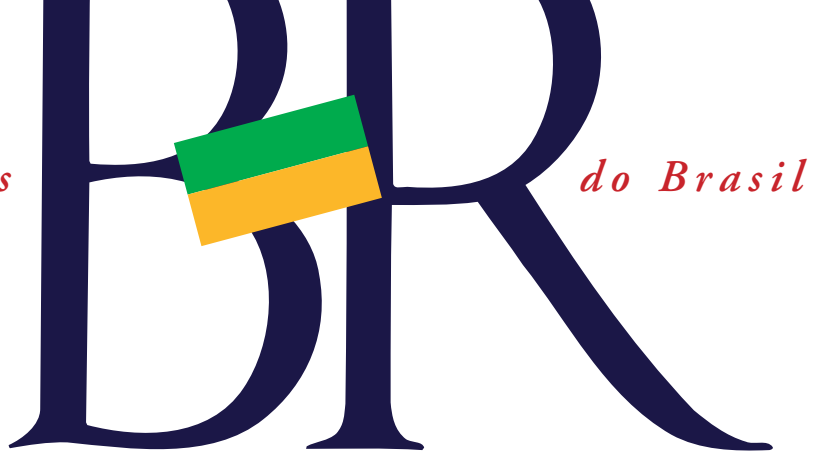

\title{
SOFTWARE LIVRE
}

\section{Movimento divulga carta aberta pelo acesso universal à informação}

Em um salão repleto de jovens hackers, estudantes, executivos, jornalistas e ativistas, 0 coordenador-geral da Associação Software Livre, Ricardo Fritsch, leu em julho uma carta aberta de preocupação com os rumos das ações do governo, durante $o$ encerramento da $13^{a}$ edição do Fórum Internacional de Software Livre (FISL), em Porto Alegre. 0 fórum ocorre anualmente na capital gaúcha, desde 2000, e funciona como catalisador de movimentos sociais e ativistas, que se reúnem sob a égide do "livre": internet livre e neutralidade, dados abertos, participação cidadã, colaboração e comunidade, sociedade em rede, inclusão digital e educação.

A carta aberta expressa a visão predominante, hoje, nesses movimentos sobre a condução de assuntos ligados à sociedade digital, dada pelo governo federal nos dois últimos anos. A retirada da licença Creative Commons - que permite modificações pelo usuário - do site do Ministério da Cultura, e a guinada na condução da reforma da Lei de Direitos Autorais, ambas ações conduzidas pela então ministra Ana 


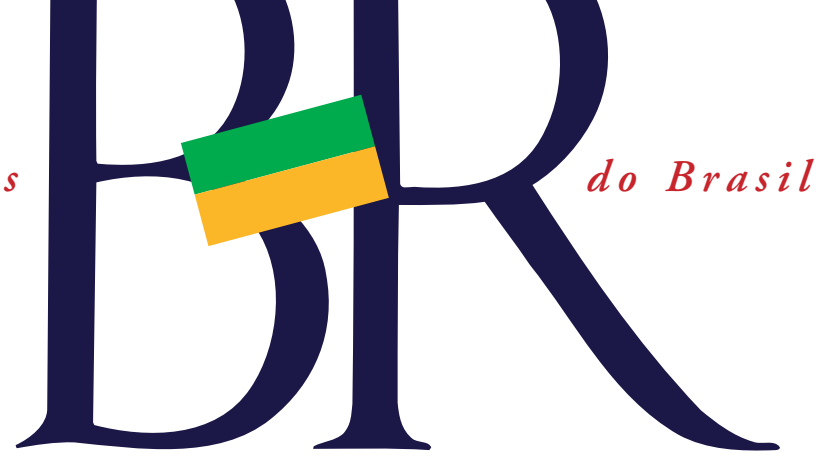

PATENTES DE SOFTWARE EM QUESTÃO

A luta contra as patentes de software, uma das principais bandeiras do Movimento do Software Livre, motiva grandes discussões. A norte-americana Free Software Foundation, por exemplo, mantém a campanha "End software patents", porque percebe as patentes como uma ameaça. É inviável para um programador independente, por exemplo, desenvolver um software livre, pesquisar e estar ciente de todas as patentes que podem incidir sobre seu trabalho. 0 texto descritivo dessas patentes é vago, de forma a cobrir uma grande área de atuação, o que cria, de fato, uma área de risco. A carta aberta também tratou do pregão eletrônico recentemente lançado pela Caixa Econômica Federal (N. 116/7066-2012 - Gilog/ BR) para aquisição de softwares proprietários da Microsoft. 0 pregão evidencia, diz o documento, que o uso do software livre no governo federal tem um de seus principais pilares ameaçado. A CEF, até recentemente, era grande usuária de software livre, além de desenvolvedora, com soluções inovadoras disponibilizadas à comunidade. 0 acesso à íntegra da carta aberta à presidenta Dilma Rousseff está no link: http:// softwarelivre.org/fisl13/noticias/ carta-a-dilma
Reprodução Humana

\section{Cresce demanda por tratamento de infertilidade, mas 0 acesso é ainda caro e seletivo}

Em 1978 nascia a inglesa Louise Brown, primeira criança concebida a partir de embrião gerado em laboratório, ou o primeiro bebê de proveta, como ficou conhecida. Tal conquista médica serviu de esperança a inúmeros casais que sonhavam com filhos, mas que tinham dificuldades reprodutivas. Em mais de três décadas, essa prática médica, que passou a ser chamada de reprodução (humana) assistida, não parou de se desenvolver e é indicada a um número cada vez maior de pacientes.

A cada ano ocorrem cerca de 2.500 procedimentos de reprodução assistida no Brasil, equivalente a um crescimento anual de 5 a $10 \%$ nos últimos cinco anos, informa o médico Édson Borges Júnior, vice-presidente da Sociedade Brasileira de Reprodução Assistida e diretor do Centro de Fertilização Assistida Fertility, de São Paulo. O novo estilo de vida dos casais modernos, que adiam a gestação, é um dos motivos para esse cenário de maior busca por tratamento reprodutivo. "Antigamente as mulheres tinham filhos mais cedo,
Reprodução

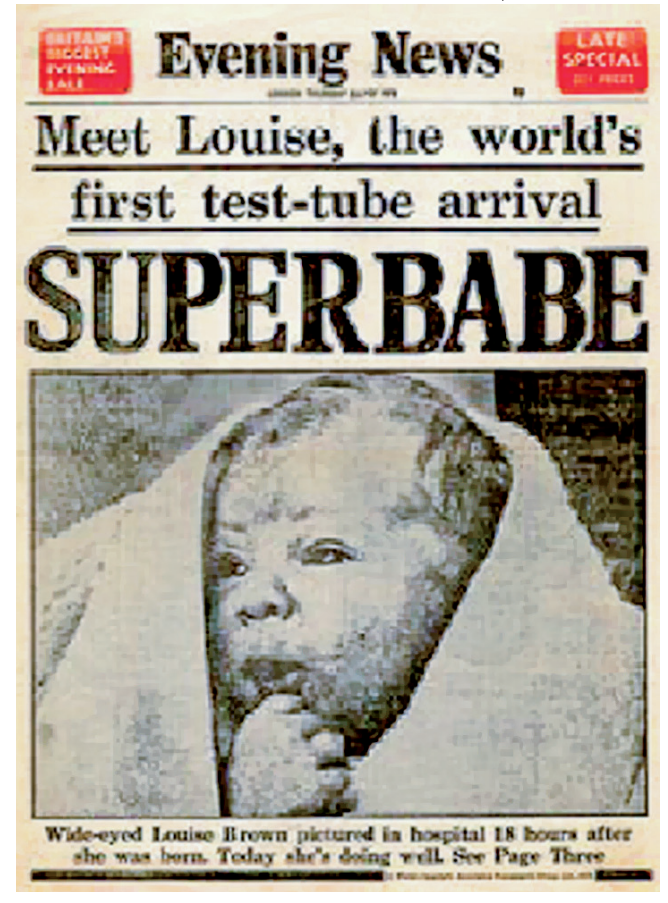

Manchete sobre bebê de proveta em 1978

entre os 20 e 30 anos; hoje, retardam a maternidade, principalmente por causa de tarefas e compromissos profissionais, o que altera a fertilidade e reduz a possibilidade de engravidar", conta Ana Carolina Japur de Sá Rosa e Silva, docente do Departamento de Ginecologia e Obstetrícia da Faculdade de Medicina de Ribeirão Preto da Universidade de São Paulo (FMRP-USP). Ela explica que, ao contrário dos homens (que produzem espermatozoides periodicamente), as mulheres possuem um número finito de gametas, cujo número diminui com o passar do tempo. "As pacientes que buscam o serviço de reprodução assistida pela primeira 